\title{
The abandoned surface mining sites in the Czech Republic: mapping and creating a database with a GIS web application
}

\author{
Richard Pokorný and Marie Tereza Peterková \\ Faculty of Environment, Jan Evangelista Purkyně University, Králova Výšina 3132/7, Ústí nad Labem, 40096, \\ Czech Republic \\ Correspondence to: Richard Pokorný (richard.pokorny@ujep.cz)
}

Received: 11 January 2016 - Published in Geosci. Instrum. Method. Data Syst. Discuss.: 26 January 2016

Revised: 5 April 2016 - Accepted: 14 April 2016 - Published: 19 May 2016

\begin{abstract}
Based on the vectorization of the 55-volume book series the Quarry Inventories of the Czechoslovak Republic/Czechoslovak Socialist Republic, published in the years 1932-1961, a new comprehensive database was built comprising 9958 surface mining sites of raw materials, which were active in the first half of the 20th century. The mapped area covers $40.9 \%$ of the territory of the Czech Republic. For the purposes of visualization, a map application, the Quarry Inventories Online, was created that enables the data visualization.
\end{abstract}

\section{Introduction}

The sites of former surface winning of mineral raw materials mirror a notable part of the heritage of every nation. They provide an overview of cultural, economic, and industrial history; they enable the study of architecture and arts; they reflect development and maturity of technologies; and they can also serve the geoscientific education of the important sites of national geoheritage (Petersen, 2002; López-García et al., 2011). Finally, they represent remarkable objects from the point of view of landscape ecology (Raška et al., 2011). In particular, small quarries in towns or villages used to be left for natural succession, and nowadays they represent important refugia increasing the biological diversity.

\section{History of the surface mining sites in the Czech Republic}

The registration of surface mining sites in the territory of the Czech Republic has a long tradition dating back to the turn of the 19th and 20th centuries. The catalogue Österreichs Steinbrüche, written in German, seems to be the oldest comprehensive list of surface mining sites in the territory of the Austro-Hungarian Empire. It mentions 1502 quarries, of which 625 are located in today's Czech Republic (436 in Bohemia, 86 in Moravia, 103 in Silesia) (Hanisch and Schmid, 1901).

In 1918, after the establishment of the independent Republic of Czechoslovakia, the distinguished Czech scientist, geologist, and contemporary head of the Czech Geological Survey (formerly the State Geological Survey of the Republic of Czechoslovakia, later renamed the Central Geological Institute) Cyril Purkyně (1862-1937) started an extensive project, the Quarry Inventories of the Czechoslovak Republic/Czechoslovak Socialist Republic (in Czech Soupisy lomu $\check{C} S R / C \zeta S S R$, hereinafter referred to as "Quarry Inventories"). The main object of the mapping was to create the catalogue of the occurrence of both abandoned quarries and locations where the mining was running. It should have given a view of the occurrence, estimated quality, and prediction of thickness and possibilities of resource utilization. Further, it should have enabled estimating the areal extension of the needed raw materials in the given area, to assess the traffic accessibility and so on. Aside from the quarries, other types of surface mining sites were also objects of interest, e.g. clay pits, loam pits, sand pits, and gravel pits. The newly established "quarry department" of the State Geological Survey was entrusted with mapping and with the formation of the Quarry Inventories (Purkyně, 1933).

The Quarry Inventories project can be divided into two periods. The publications were elaborated according to the area of the former administrative districts in the years 1932- 
1951. Forty-one of them were mapped (Gotthard, 1932; Vachtl, 1933, 1934a, b, 1935, 1947, 1949a, b; Kratochvíl and Zabloudil, 1934; Urban, 1935; Procházka, 1939; Soukup, 1940; Tuček, 1940; Vavř́nová, 1940, 1946, 1948a, 1949, 1950; Žebera, 1941; Hejtman, 1942, 1948a, b; Rost, 1942; Polák, 1946a, b, c, 1948a, b, 1949; Pauk, 1947; Pokorný, 1947, 1948, 1950; Prokop, 1948, 1949a, b; Kalášek and Polák, 1950; Šob, 1950; Prokop and Vachtl, 1951), for the following two districts separate supplements were published (Pauk, 1948; Vavř́nová, 1948b), and one district belongs to the Slovak Republic nowadays (Fiala, 1934).

The area of interest in the single volumes of the Quarry Inventories was unified according to map sheets on a scale of 1:75000 in the period 1947-1961, whereas in sporadic cases duplicate mapping of the already processed area was performed. In such cases the data were updated in the new volume - for instance when the quarry was no longer functioning, or when a newly opened mining site was detected next to an already known object, when new details on mining were obtained. In this period, 13 map sheets were mapped and published (Polák, 1951a, b, 1956; Vavřínová, 1951, 1952, 1961; Frejková, 1952; Kalášek, 1952; Prokop, 1952; Vavř́nová and Líbalová, 1959; Líbalová, 1961a, b; Fajst and Holásek, 1961).

Concurrently to the Quarry Inventories project, primarily targeted on the Bohemian part of Czechoslovakia, 20 map sheets named "Map of the Building Materials in the Czechoslovak Republic" (in Czech Mapa stavebných hmôt Československej republiky) were edited in Slovakia by the - at that time still independent - State Geological Institute in Bratislava. Only a part of this set of 20 map sheets were printed in the form of an explanatory text to the Quarry Inventories (Katyk, 1949, 1950a, b, 1951a, b, c, d, e; Zorkovský, 1951); the rest are located as author manuscript map sheets at ČGS - department Geofond.

Single volumes of the Quarry Inventories project were published in the form of sewn-bound, hardbound, or paperback booklets in A5 size (or similar). In the exordium, basic data concerning the geology of the mapped area and the history of preceding research in the area of interest are briefly summarized. Lists of surface mining sites represent the central part of each volume. The lists are aligned according to appropriate cadastral areas, and they describe about 20 characteristic of the mining site, using a unified template. Mentioned are the owner of the site, mileage to the nearest railway station, form of the access road, petrographic name of the rock, geological period, colour, granularity, porosity, hardness, polishability, method of mining, size of the site, number of employees, annual amount extracted, etc. The list of remarkable buildings where constructional materials from the site were used is an important but not always mentioned category.

The volumes have separate appendices - schematic or topographic maps of former districts or map sheets. Some of the volumes of the Quarry Inventories also contain attached
Table 1. Size characteristics of the mining sites. Small: up to $1000 \mathrm{~m}^{2}$; medium: $1000-10000 \mathrm{~m}^{2}$; large: above $10000 \mathrm{~m}^{2}$. Note: "_" is the category of mining sites not classified in detail.

\begin{tabular}{|c|c|c|c|c|c|}
\hline & Small & Middle & Large & $\begin{array}{l}\text { No } \\
\text { data }\end{array}$ & $\Sigma$ \\
\hline Stone quarry & 3498 & 2014 & 184 & 1017 & 6713 \\
\hline Gravel pit & 4 & 10 & 0 & 51 & 65 \\
\hline $\begin{array}{l}\text { Combined gravel pit }+ \\
\text { sand quarry }\end{array}$ & 0 & 2 & 0 & 33 & 35 \\
\hline Sand quarry & 455 & 27 & 1 & 1465 & 1948 \\
\hline Loam pit & 0 & 7 & 8 & 585 & 600 \\
\hline Clay pit & - & - & - & 228 & 228 \\
\hline Loam or clay pit (unspecified) & 1 & 2 & 0 & 334 & 337 \\
\hline $\begin{array}{l}\text { Combined loam pit }+ \\
\text { sand quarry }\end{array}$ & 0 & 2 & 1 & 2 & 5 \\
\hline Kaolin pit & - & - & - & 17 & 17 \\
\hline Unspecified raw material & - & - & - & 10 & 10 \\
\hline
\end{tabular}

sections that - on a smaller scale - illustrate selected parts of the surveyed area with a higher density of mining sites.

At the beginning of the 1960s, the quarry department of the State Geological Survey was abolished and the project Quarry Inventories was terminated without having mapped the whole territory of Czechoslovakia. We may assume that the reason for the shutdown was the fact that for communist Czechoslovakia - where the proprietorship of raw material deposits was suppressed - running small local quarries was non-profitable when new large opencasts were opened up (Peterková, 2015).

Disregarding the fact that the Quarry Inventories project had not been finalized, $40.9 \%$ of the territory of the contemporary Czech Republic in 55 published volumes was processed.

\section{Methods of georeferencing, vectorization, and building the database}

Map attachments of the published Quarry Inventories were digitized by a large-format scanner into the form of a noncompressed raster in tiff format. In ArcGIS 10.2, control points, identical both in the referential background map and in the embedded raster, were identified and created. Georeferencing was done in the geographical grid system SJTSK_Krovak_East_North.

After georeferencing of all raster data, a punctual vector layer file with a table of attributes was created, containing columns for a follow-up adding of text information (type, extent, character of the mining site, serial number in the published volume, district). The metadata database creation allowed sorting the mining sites by their type, size, and main used technology (Tables 1,2). The consecutive handmade vectorization of opencast objects from raster maps was the most time-consuming activity (Figs. 1, 2).

In single cases, when the volume of the Quarry Inventories was published without a map supplement, original 


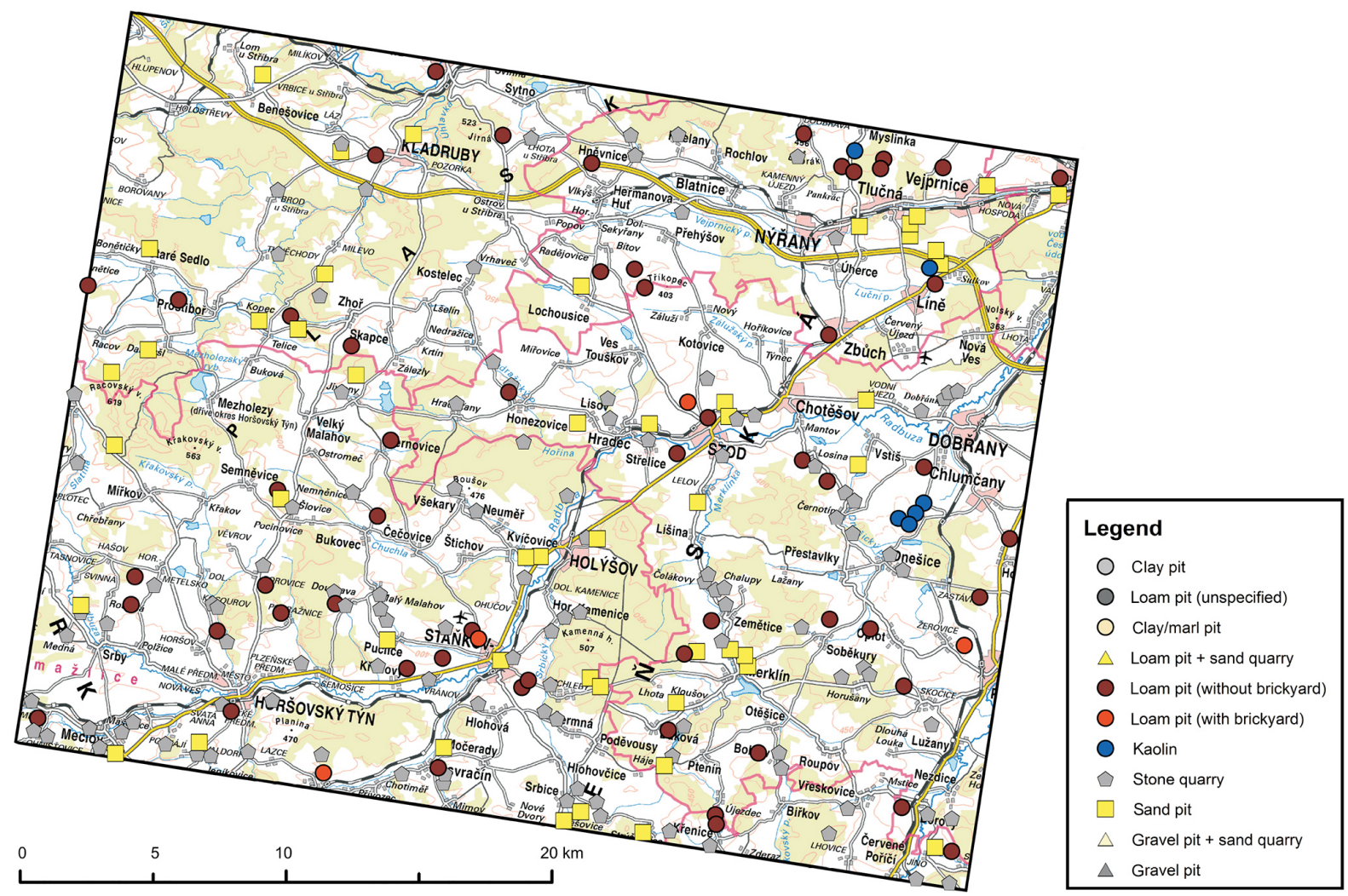

Figure 1. Example of the mining site distribution in the map sheet of the special map 1 : 75000 Horšovský Týn 4150.

Table 2. Mining sites sorted by main used technologies. Note: “-” is the category of mining sites not classified in detail.

\begin{tabular}{lcccc}
\hline & $\begin{array}{c}\text { Pit } \\
\text { quarry }\end{array}$ & $\begin{array}{c}\text { Shelf } \\
\text { quarry }\end{array}$ & $\begin{array}{c}\text { No } \\
\text { data }\end{array}$ & $\Sigma$ \\
\hline Stone quarry & 1586 & 5043 & 84 & 6713 \\
Gravel pit & 35 & 10 & 20 & 65 \\
Combined gravel pit + sand quarry & 11 & 24 & 0 & 35 \\
Sand quarry & 226 & 1417 & 305 & 1948 \\
Loam pit & 47 & 232 & 321 & 600 \\
Clay pit & 31 & 126 & 71 & 228 \\
Loam or clay pit (unspecified) & 18 & 292 & 27 & 337 \\
Combined loam pit + sand quarry & 1 & 4 & 0 & 5 \\
Kaolin pit & 2 & 0 & 15 & 17 \\
Unspecified raw material & - & - & 10 & 10 \\
\hline
\end{tabular}

manuscripts were used for localization and vectorization (Polák 1951a, b, 1956; Prokop, 1952; Kalášek, 1952). In three volumes, the maps were not preserved. In these cases the localization and consecutive vectorization of surface mining sites were carried out based on a written description only (Frejková, 1952; Vavř́nová, 1951, 1952).

In all, 9958 objects have been vectorized. The standard deviation of the vectorization accuracy is up to $150 \mathrm{~m}$ because of the inconsistent quality of graphic processing and preservation of map supplements of the Quarry Inventories.
For the purpose of spatial analyses, the vector layer in form of polygons was generated which should be instrumental for recording the area of particular districts and map sheets. The calculation of areas was done by means of the function "Calculate Geometry" (Fig. 3).

In order to enable the online visualization of generated data, the GIS project was appended with metadata (title, summary, description, and tags); then the project with all vector layers was saved by means of the function "Create Map Package" and uploaded to the mapping cloud platform ArcGIS Online. Herein a web map composition and lastly a final web map application in form of the hosted feature service the Quarry Inventories Online was created and configured.

\section{Discusion and conclusions}

The project of vectorization of the surface mining sites, rising from the collection of volumes of the Quarry Inventories of the Czechoslovak Republic/Czechoslovak Socialist Republic, maps the condition of objects which were active in the first half of the 20th century mainly. Thus, its scope in time is deeper than other similar projects in the Czech Republic - such as "Stones, Sandpits and Limestone quarries in the Czech Republic", mapping the currently quarried raw materials sources used especially for renewal of 


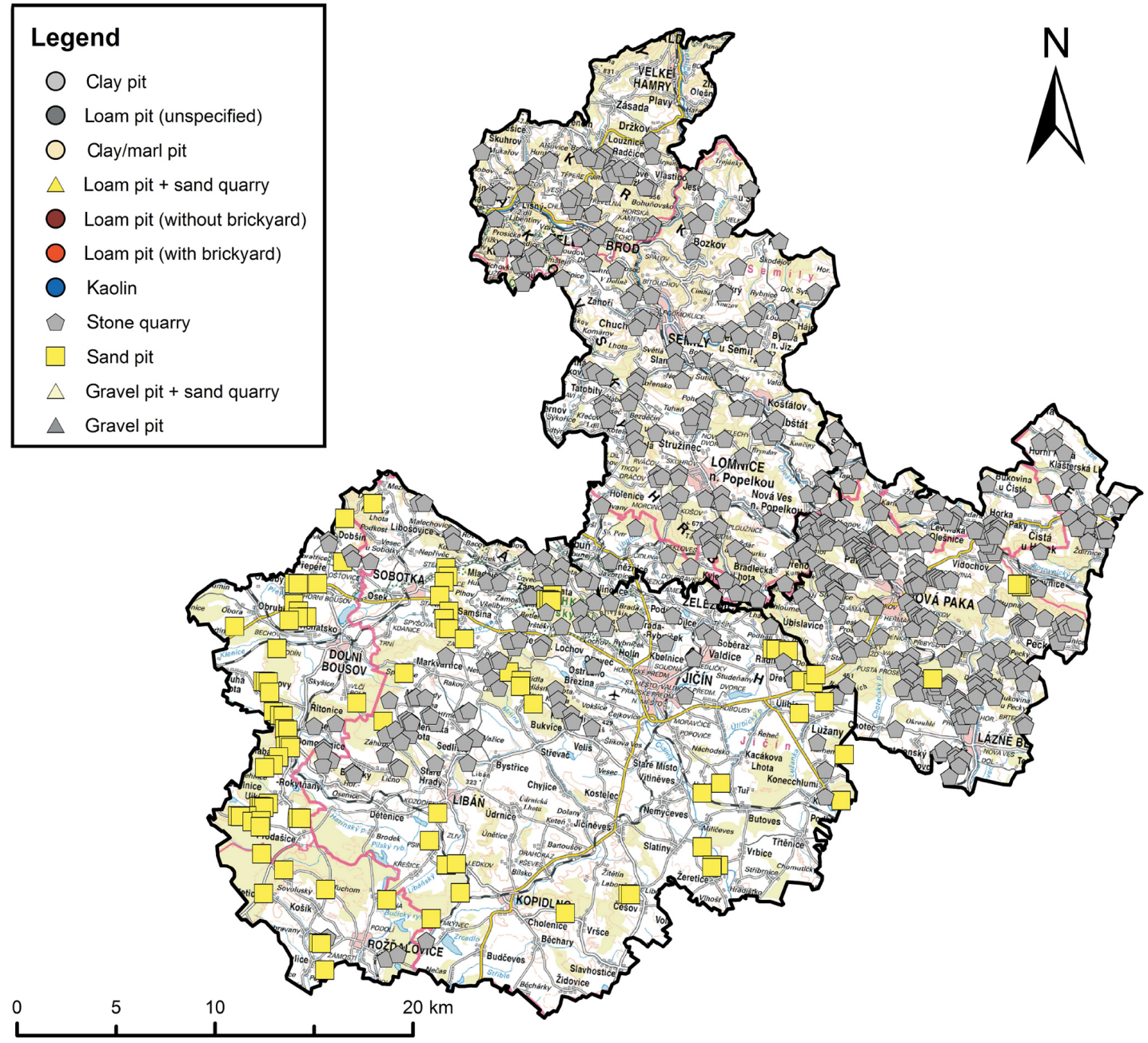

Figure 2. Example of the mining site distribution in three districts (top: Semily; right: Nová Paka; bottom: Jičín).

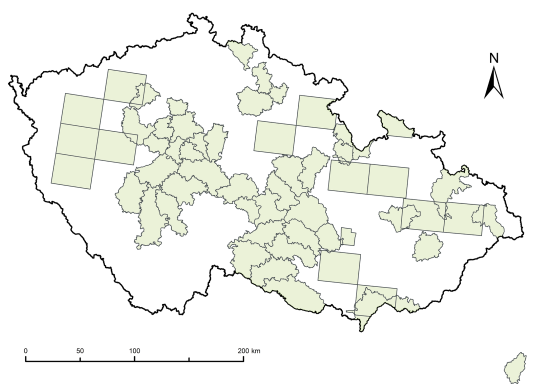

Figure 3. Areal extents of the districts and the map sheets processed in the published Quarry Inventories project volumes.

cultural heritage (Koutník, 2015), or the equally specialized application "Decorative Stones" (Dudíková Schulmannová and Skarková, 2010; Paleček et al., 2014). Historical sites of opencast mining of raw materials in a wider European space are mapped by the project "Historic Quarries", which covers - aside from several locations in the Czech Repub- lic - mainly the territory of Slovakia, Poland, Hungary, Austria, and Ukraine (Uhlir and Schaller, 2008-2010; Uhlir et al., 2013). Available online, in form of a database without map application, are the services "Italithos" (Giampaolo et al., 2000-2013) and the "Stone Quarries Database" (Russell, 2010), specialized mainly in raw materials mining in the era of the Roman Empire.

The map application Quarry Inventories represents with its almost 10000 entries the most comprehensive survey of abandoned surface mining sites of raw materials in the territory of one state. Most frequent are categories of small and medium-sized stone quarries with an area up to $10000 \mathrm{~m}^{2}$ (5512 in total) and small sand quarries with an area up to $1000 \mathrm{~m}^{2}$ (455 in total). Only 194 mining sites can be defined as large, covering an area over $10000 \mathrm{~m}^{2}$. In relation to the used mining technology, the shelf quarries prevailed over the pit quarries $(71.8,19.7,8.5 \%$ - no data); see Tables 1 and 2 .

Considering the fact that in the published volumes of the Quarry Inventories less than a half of the Czech Republic 


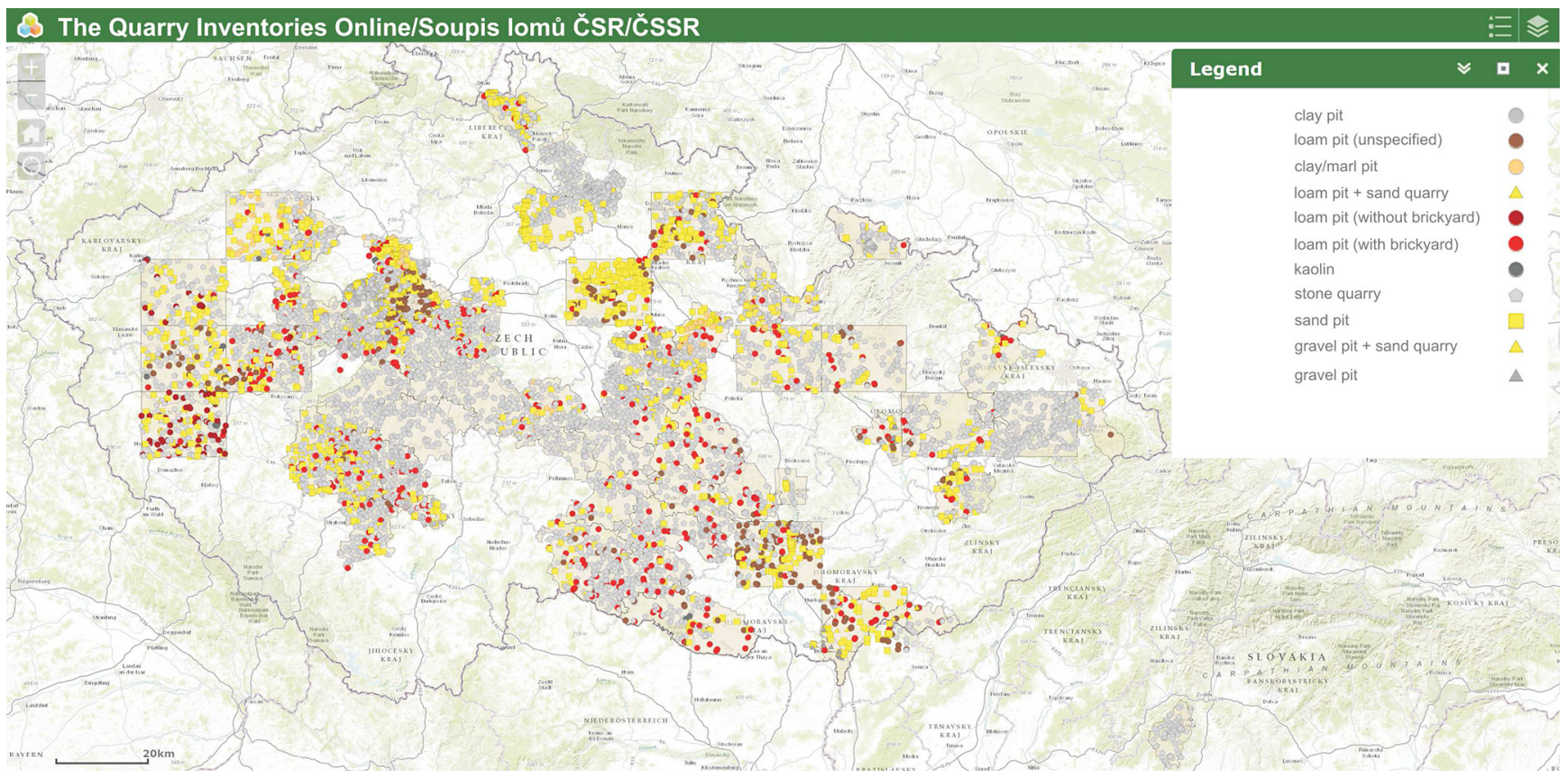

Figure 4. Screenshot of "the Quarry Inventories Online" web map application.

(40.9\%) was mapped, the real number of active quarries in the first half of the 20th century can be estimated at ca. 20000-25 000. This corresponds to the average distributions of the quarries per each 3-4 km² (Peterková, 2015).

In time to come, therefore, a widening of the database is planned in several steps. First, data will be processed from similarly specialized manuscripts written after the publishing of the Quarry Inventories had been terminated (theses, paper card indexes, etc.). In areas where no inventory analyses have been done, air photos from the years 1937-1970 will be utilized (SINE, 2010).

The final and most time-consuming phase will be a field survey focused both on verification of existing entries and on completely new and still unmapped objects.

\section{Data availability}

The web map application Quarry Inventories Online is accessible at http://mapserver.ujep.cz/seminarky/bp-peterkova/ (Fig. 4). GIS software users can display all layers as web map service sublayers (WMS) based on the client-server principle at http://195.113.140.12/arcgis/services/Projekty/ (Peterková, 2015).

Acknowledgements. The project was supported by a grant within the student grant competition at UJEP (Jan Evangelista Purkyně University) in Ústí nad Labem (no. 1/2014). Authors gratefully acknowledge the two last living authors of the "Quarry Inventories", Jana Líbalová and Oldřich Holásek, for their constructive comments and discussions of the manuscript. Special thanks to the referees for their thoughtful and thorough reviews.
Edited by: L. Eppelbaum

\section{References}

Dudíková Schulmannová, B. and Skarková, H.: New internet database of decorative and building stones of the Czech Republic, Czech Geological Survey, Prague, Geoscience Research Reports for 2009, 297-299, 2010 (in Czech, English abstract).

Fajst, M. and Holásek, O.: The quarry inventories of the Czechoslovak Socialist Republic. 55 - map sheet of the special map 1 : 75000 Náchod 3856, Central Geological Institute, Prague, 1961 (in Czech).

Fiala, F.: The quarry inventories of the Czechoslovak Republic. $4-$ Banská Štiavnica district, Czech. Uni. Res. Test. Tech. Imp. Mat. Struct. and St. Geol. Sur. (in Czech: Československý svaz pro výzkum a zkoušení technicky důležitých látek a konstrukcí spolu se Státním ústavem geologickým), Prague, 1934 (in Czech).

Frejková, L.: The quarry inventories of the Czechoslovak Republic. 45 - map sheet Nový Jičín 4160, Central Geological Institute, Prague, 1952 (in Czech).

Giampaolo, C., Adanti, B., and Di Pace, A.: Italithos. Roma Tre University, Roma, available at: http://www.italithos.uniroma3.it, last access: 10 December 2015, 2000-2013.

Gotthard, J.: The quarry inventories of the Czechoslovak Republic. 1 - Semily district, Czech. Uni. Res. Test. Tech. Imp. Mat. Struct. and St. Geol. Sur., Prague, 1932 (in Czech).

Hanisch, A. and Schmid, H.: Austrian Quarries, Verlag von Carl Graeser \& Co, Wien, 1901 (in German).

Hejtman, B.: The Quarries of Bohemia and Moravia. 15 - former Milevsko district, Agency for Research on Soil in Bohemia and Moravia, Prague, 1942 (in Czech). 
Hejtman, B.: The quarry inventories of the Czechoslovak Republic. 25 - Písek district, Czech. Uni. Res. Test. Tech. Imp. Mat. Struct. and St. Geol. Sur., Prague, 1948a (in Czech).

Hejtman, B.: The quarry inventories of the Czechoslovak Republic. 26 - Český Brod district, Czech. Uni. Res. Test. Tech. Imp. Mat. Struct. and St. Geol. Sur., Prague, 1948b (in Czech).

Kalášek, J.: The quarry inventories of the Czechoslovak Republic. 49 - map sheet Hodonín 4458, Central Geological Institute, Prague, 1952 (in Czech).

Kalášek, J. and Polák, A.: The quarry inventories of the Czechoslovak Republic. 41 - Moravské Budějovice district, Central Geological Institute, Prague, 1950 (in Czech).

Katyk, M.: Building materials of the Czechoslovak Republic. Map sheet Pieštany 4559 - Slovakia, Stud. St. Geol. Inst., Bratislava, 19, 1-99, 1949 (in Slovak).

Katyk, M.: Building materials of the Czechoslovak Republic. Map sheet Senec 4759 - Slovakia, Stud. St. Geol. Inst., Bratislava, 21, 1-67, 1950a (in Slovak).

Katyk, M.: Building materials of the Czechoslovak Republic. Map sheet Trnava 4659 - Slovakia, Stud. St. Geol. Inst., Bratislava, 22, 1-71, 1950b (in Slovak).

Katyk, M.: Building materials of the Czechoslovak Republic. Map sheet Dunajská Streda 4859 and Klížska Nemá 4959 - Slovakia, Slov, Geot., 4, 1-39, 1951a (in Slovak).

Katyk, M.: Building materials of the Czechoslovak Republic. Map sheet Komárno 4860 and Iža 4960 - Slovakia, Slov, Geot., 5, 128, $1951 b$ (in Slovak).

Katyk, M.: Building materials of the Czechoslovak Republic. Map sheet Lanžhot 4558 - Slovakia, Slov, Geot., 1, 1-36, 1951c (in Slovak).

Katyk, M.: Building materials of the Czechoslovak Republic. Map sheet Malacky 4658 - Slovakia, Slov, Geot., 2, 1-47, 1951d (in Slovak).

Katyk, M.: Building materials of the Czechoslovak Republic. Map sheet Šurany 4658 - Slovakia, Slov, Geot., 3, 1-35, 1951e (in Slovak).

Koutník, P.: Stones, sandpits and limestone quarries in the Czech Republic, Faculty of Environment, J. E. Purkyně University in Ústí nad Labem, Ústí nad Labem, Czech Republic, available at: http://mapserver.ujep.cz/Projekty/Databaze_ dekorativniho_kamene/ (last access: 10 December 2015), 2015.

Kratochvíl, J. and Zabloudil, J.: The quarry inventories of the Czechoslovak Republic. 5 - Humpolec district, Czech. Uni. Res. Test. Tech. Imp. Mat. Struct. and St. Geol. Sur., Prague, 1934 (in Czech).

Líbalová, J.: The quarry inventories of the Czechoslovak Socialist Republic. 52 - map sheet of the special map 1:75000 Horšovský Týn 4150, Central Geological Institute, Prague, 1961a (in Czech).

Líbalová, J.: The quarry inventories of the Czechoslovak Socialist Republic. 53 - map sheet of the special map 1:75000 Karlovy Vary 3950, Central Geological Institute, Prague, 1961b (in Czech).

López-García, J. A., Oyarzun, R., López Andrés, S., and Manteca Martínez, J. I.: Scientific, Educational, and Environmental Considerations Regarding Mine Sites and Geoheritage: A Perspective from SE Spain, Geoheritage, 3, 267-275, 2011.

Paleček, M., Pospíšil, V., and Skarková, H.: Decorative stones. Czech Geologic Survey, Prague, avail- able at: http://mapy.geology.cz/dekoracni_kameny/ and http://dekoracni-kameny.geology.cz, last access: 10 December 2015, 2014.

Pauk, F.: The quarry inventories of the Czechoslovak Republic. 21 Chotěboř district, Czech. Uni. Res. Test. Tech. Imp. Mat. Struct. and St. Geol. Sur., Prague, 1947 (in Czech).

Pauk, F.: The quarry inventories of the Czechoslovak Republic. 24 - Nová Paka district (addendum), Czech. Uni. Res. Test. Tech. Imp. Mat. Struct. and St. Geol. Sur., Prague, 1948 (in Czech).

Peterková, M. T.: Digitalization of the book series "Soupisy lomů ČSR/ČSSR", BSc thesis, J. E. Purkyně University in Ústí nad Labem, 2015 (in Czech, English abstract).

Petersen, J.: The role of roadcuts, quarries, and other artificial exposures in geomorphology education, Geomorphology, 47, 289301, 2002.

Pokorný, M.: The quarry inventories of the Czechoslovak Republic. 20 - Holešov district, Czech. Uni. Res. Test. Tech. Imp. Mat. Struct. and St. Geol. Sur., Prague, 1947 (in Czech).

Pokorný, M.: The quarry inventories of the Czechoslovak Republic. 34 - Opava district, Czech. Uni. Res. Test. Tech. Imp. Mat. Struct. and St. Geol. Sur., Prague, 1948 (in Czech).

Pokorný, M.: The quarry inventories of the Czechoslovak Republic. 40 - Olomouc district, Czech. Uni. Res. Test. Tech. Imp. Mat. Struct. and St. Geol. Sur., Prague, 1950 (in Czech).

Polák, A.: The quarry inventories of the Czechoslovak Republic. 17 - Tišnov district, Czech. Uni. Res. Test. Tech. Imp. Mat. Struct. and St. Geol. Sur., Prague, 1946a (in Czech).

Polák, A.: The quarry inventories of the Czechoslovak Republic. 18 - Nové Město na Moravě district, Czech. Uni. Res. Test. Tech. Imp. Mat. Struct. and St. Geol. Sur., Prague, 1946b (in Czech).

Polák, A.: The quarry inventories of the Czechoslovak Republic. 19 - Velké Meziříčí district, Czech. Uni. Res. Test. Tech. Imp. Mat. Struct. and St. Geol. Sur., Prague, 1946c (in Czech).

Polák, A.: The quarry inventories of the Czechoslovak Republic. 28 - Jihlava district, Czech. Uni. Res. Test. Tech. Imp. Mat. Struct. and St. Geol. Sur., Prague, 1948a (in Czech).

Polák, A.: The quarry inventories of the Czechoslovak Republic. 30 - Znojmo district, Czech. Uni. Res. Test. Tech. Imp. Mat. Struct. and St. Geol. Sur., Prague, 1948b (in Czech).

Polák, A.: The quarry inventories of the Czechoslovak Republic. 35 - Dačice district, Czech. Uni. Res. Test. Tech. Imp. Mat. Struct. and St. Geol. Sur., Prague, 1949 (in Czech).

Polák, A.: The quarry inventories of the Czechoslovak Republic. 43 - map sheet Pardubice - Hradec Králové 3955, Central Geological Institute, Prague, 1951a (in Czech).

Polák, A.: The quarry inventories of the Czechoslovak Republic. 44 - map sheet of the special map Šumperk 4058, Central Geological Institute, Prague, 1951b (in Czech).

Polák, A.: The quarry inventories of the Czechoslovak Republic. 50 - map sheet Brno 4357, Central Geological Institute, Prague, 1956 (in Czech).

Procházka, V.: The quarry inventories of the Czechoslovak Republic. 9 - Německý Brod district, Czech. Uni. Res. Test. Tech. Imp. Mat. Struct. and St. Geol. Sur., Prague, 1939 (in Czech).

Prokop, F.: The quarry inventories of the Czechoslovak Republic. 23 - Liberec district, Czech. Uni. Res. Test. Tech. Imp. Mat. Struct. and St. Geol. Sur., Prague, 1948 (in Czech). 
Prokop, F.: The quarry inventories of the Czechoslovak Republic. 32 - Blatná district, Czech. Uni. Res. Test. Tech. Imp. Mat. Struct. and St. Geol. Sur., Prague, 1949a (in Czech).

Prokop, F.: The quarry inventories of the Czechoslovak Republic. 37 - Chrudim and Hlinsko district, Czech. Uni. Res. Test. Tech. Imp. Mat. Struct. and St. Geol. Sur., Prague, 1949b (in Czech).

Prokop, F.: The quarry inventories of the Czechoslovak Republic. 48 - map sheet Javorník 3858, Central Geological Institute, Prague, 1952 (in Czech).

Prokop, F. and Vachtl, J.: The quarry inventories of the Czechoslovak Republic. 42 - Prague-city and Prague-countryside/north districts, Central Geological Institute, Prague, 1951 (in Czech).

Purkyně, C.: Report on the activities of the State Geological Institute of the Czechoslovak Republic, Bull. St. Geol. Inst., 9, 1-24, 1933 (in Czech).

Raška, P., Balej, M., and Raška, M.: Differential evolution of rockwall and talus cones in abandoned basalt quarries and its implications for restoration management: case study from the Radobyl Hill, N Czech Republic, International Journal of Mining, Reclamation and Environment, 25, 297-312, 2011.

Rost, R.: The Quarries of Bohemia and Moravia. 14 - Kralupy nad Vltavou district, Agency for Research on Soil in Bohemia and Moravia, Prague, 1942 (in Czech).

Russell, B. (database coordinator): Stone Quarries Database, in The Oxford Roman Economy Project. University of Oxford, Oxford, available at: http://oxrep.classics.ox.ac.uk/databases/stone_ quarries_database/, last access: 10 December 2015, 2010.

SINE: Historical aerial images, CENIA and GEODIS Brno, available at: http://kontaminace.cenia.cz/, last access: 10 December $2015,2010$.

Šob, A.: The Quarry Inventories of the Czechoslovak Republic. 36 - Hodonín district, Czech. Uni. Res. Test. Tech. Imp. Mat. Struct. and St. Geol. Sur., Prague, 1950 (in Czech).

Soukup, J.: The Quarry Inventory. 10 - Jičín district, Cz. Uni. f. Res. and Test. of Tech. Imp. Mat. and Struct. in coop. w. Geol. Inst. of Boh. and Mor. (in Czech: Český svaz pro výzkum a zkoušení technicky důležitých látek a konstrukcí spolu s Geologickým ústavem pro Čechy a Moravu), Prague, 1940 (in Czech).

Tuček, K.: The Quarry Inventory. 11 - Nová Paka district, Cz. Uni. f. Res. and Test. of Tech. Imp. Mat. and Struct. in coop. w. Geol. Inst. of Boh. and Mor., Prague, 1940 (in Czech).

Uhlir, C. and Schaller, K.: Historic Quarries. University of Salzburg, Salzburg, available at: http://www.historic-quarries.org/map, last access: 10 December 2015, 2008-2010.

Uhlir, C., Schaller, K., and Unterwurzacher, M.: Historic Quarries: Case Studies, in: Scientific Computing and Cultural Heritage: Contributions in Computational Humanities, edited by: Bock, H. G., Jäger, W., and Winckler, M. J., Springer-Verlag, Berlin, Heidelberg, 245-254, 2013.

Urban, K.: The quarry inventories of the Czechoslovak Republic. 7 - Louny district, Czech. Uni. Res. Test. Tech. Imp. Mat. Struct. and St. Geol. Sur., Prague, 1935 (in Czech).

Vachtl, J.: The quarry inventories of the Czechoslovak Republic. 2 Sedlčany district, Czech. Uni. Res. Test. Tech. Imp. Mat. Struct. and St. Geol. Sur., Prague, 1933 (in Czech).

Vachtl, J.: The quarry inventories of the Czechoslovak Republic. 3 - Jílové district, Czech. Uni. Res. Test. Tech. Imp. Mat. Struct. and St. Geol. Sur., Prague, 1934a (in Czech).
Vachtl, J.: The quarry inventories of the Czechoslovak Republic. 6 - Benešov district, Czech. Uni. Res. Test. Tech. Imp. Mat. Struct. and St. Geol. Sur., Prague, 1934b (in Czech).

Vachtl, J.: The quarry inventories of the Czechoslovak Republic. 8 - Př́bram district, Czech. Uni. Res. Test. Tech. Imp. Mat. Struct. and St. Geol. Sur., Prague, 1935 (in Czech).

Vachtl, J.: The quarry inventories of the Czechoslovak Republic. 22 - Rakovník district, Czech. Uni. Res. Test. Tech. Imp. Mat. Struct. and St. Geol. Sur., Prague, 1947 (in Czech).

Vachtl, J.: The quarry inventories of the Czechoslovak Republic. 31 - Beroun district, Czech. Uni. Res. Test. Tech. Imp. Mat. Struct. and St. Geol. Sur., Prague, 1949a (in Czech).

Vachtl, J.: The quarry inventories of the Czechoslovak Republic. 39 - Prague-south district, Czech. Uni. Res. Test. Tech. Imp. Mat. Struct. and St. Geol. Sur., Prague, 1949b (in Czech).

Vavřínová, M.: The Quarries of Bohemia and Moravia. 12 - Žamberk district, Geological Institute of Bohemia and Moravia, Prague, 1940 (in Czech).

Vavřínová, M.: The quarry inventories of the Czechoslovak Republic. 16 - Říčany district, Czech. Uni. Res. Test. Tech. Imp. Mat Struct. and St. Geol. Sur., Prague, 1946 (in Czech).

Vavřínová, M.: The quarry inventories of the Czechoslovak Republic. 27 - Třebíč district, Czech. Uni. Res. Test. Tech. Imp. Mat. Struct. and St. Geol. Sur., Prague, 1948a (in Czech).

Vavřínová, M.: The quarry inventories of the Czechoslovak Republic. 29 - Žamberk district (addendum), Czech. Uni. Res. Test. Tech. Imp. Mat. Struct. and St. Geol. Sur., Prague, 1948b (in Czech).

Vavřínová, M.: The quarry inventories of the Czechoslovak Republic. 33 - Vysoké Mýto district, Czech. Uni. Res. Test. Tech. Imp. Mat. Struct. and St. Geol. Sur., Prague, 1949 (in Czech).

Vavřínová, M.: The quarry inventories of the Czechoslovak Republic. 38 - Ledeč nad Sázavou district, Czech. Uni. Res. Test. Tech. Imp. Mat. Struct. and St. Geol. Sur., Prague, 1950 (in Czech).

Vavřínová, M.: The quarry inventories of the Czechoslovak Republic. 46 - sheet Kralovice 4051, Central Geological Institute, Prague, 1951 (in Czech).

Vavřínová, M.: The quarry inventories of the Czechoslovak Republic. 47 - map sheet Česká Třebová 4057, Central Geological Institute, Prague, 1952 (in Czech).

Vavřínová, M.: The quarry inventories of the Czechoslovak Socialist Republic. 54 - map sheet of the special map 1:75000 Chomutov 3851, Central Geological Institute, Prague, 1961 (in Czech).

Vavřínová, M., and Líbalová, J.: The quarry inventories of the Czechoslovak Republic. 51 - map sheet of the special map 1 : 75000 Teplá 4050, Central Geological Institute, Prague, 1959 (in Czech).

Zorkovský, B.: Building materials of the Czechoslovak Republic. Map sheet Ružomberok 4362, Slovak Geotechnics, 6, 1-29, 1951 (in Slovak).

Žebera, K.: The Quarries of Bohemia and Moravia. 13 - Kladno district, Cz. Uni. f. Res. and Test. of Tech. Imp. Mat. and Struct. in coop. w. Geol. Inst. of Boh. and Mor., Prague, 1941 (in Czech). 